Kong. Res. J. 1(1) : 65-68, 2014

Kongunadu Arts and Science College, Coimbatore

\title{
PHYTOCHEMICAL SCREENING OF COSTUS MEXICANUS LIEBM. - AN INSULIN PLANT
}

\author{
Sindhu, $S$.* and S. Manorama \\ Department of Botany, Kongunadu Arts and Science College, Coimbatore. \\ *E.mail - ssindhu389@gmail.com
}

\begin{abstract}
Phytochemicals are extensively found at different levels in many medicinal plants. Costus mxicanus an important medicinal plant belongs to the family Costaceae. It is used for diabetics by traditional healers. The present study was undertaken to investigate the preliminary phytochemicals in the petroleum ether, acetone and ethanol extracts of leaves, stem and rhizome of Costus mexicanus Liebm. and the study revealed the presence of alkaloid, flavanoid, terepenoid in the Costus mexicanus.
\end{abstract}

Keywords: Costus mexicanus, preliminary phytochemical.

\section{INTRODUCTION}

Medicinal plants are of great importance to the health of individual and communities. The medicinal value of these plants lies in some chemical active substances that produce a definite physiological action on the human body. The most important of these chemically active (bioactive) constituents of plants are: alkaloids, tannin, flavonoid and phenolic compounds. Many of these indigenous medicinal plants are also used for medicinal purposes (Edeoga et. al., 2005).

A knowledge of the chemical constituents of plants is desirable, not only for the discovery of therapeutic agents, but also because such information may be of value in disclosing new sources of such economic materials as tannins, oils, gums, precursors for the synthesis of complex chemical substances, etc. In addition, the knowledge of the chemical constituents of plants would further be valuable in discovering the actual value of folkloric remedies (Farnsworth, 1966).

Costus is a genus of perennial tropical herbaceous plants from the costus family (Costaceae). Costus mexicanus Liebm. is also known as Insulin plant. It is used as a munching supplementary food for the treatment of diabetes. In Mexico, it is used to treat renal disease (Martinez, 1996; Rzedowski, 1979; Caceres et. al., 1987; Argueta et. al., 1994). It is reported to have effects on renal functions and its anti-inflammatory, hypoglycemic actions (Martinez, 1996 and Merina, 2004) and ant diabetic property (Merina, 2005 and Nandhakumar et. al., 2007).The plant is also rich in antioxidants (Shubha, 2010). The plant was reported to contain flavonoids, saponins, reduced sugars and tannins (Comargo et. al., 2006). Hence, this study was designed to undertake the physicochemical and phytochemical screening of various extracts of Costus mexicanus.

\section{MATERIALS AND METHODS}

\subsection{Collection and identification of plant materials}

The leaves, stem and rhizome of C.maxicana were collected from Kannur, Kerala and authenticated by Botanical survey of India, Coimbatore. The voucher specimen of the plant was deposited at the college for further reference.

\subsection{Extraction of plant materials}

The plant materials (leaves, stem and rhizome of C.maxicana) were air-dried at room temperature $\left(26^{\circ} \mathrm{C}\right)$ for 2 weeks, after which it was grinded to a uniform powder. The petroleum ether, acetone and ethanol extracts were prepared by soaking $50 \mathrm{~g}$ each of the dry powdered plant materials in $300 \mathrm{~L}$ of ethanol at room temperature for $48 \mathrm{~h}$. The extracts were filtered after $48 \mathrm{~h}$, first through a Whatmann filter paper No. $42(125 \mathrm{~mm})$ and then through cotton wool. The extracts were concentrated using a rotary evaporator with the water bath set at $40^{\circ} \mathrm{C}$.

\subsection{Physicochemical Analysis:}

The coarse powder of leaves, stem and rhizome of Costus mexicanus was subjected to various physicochemical studies for determination of ash values and extractive values.

\subsubsection{Qualitative screening}

The dried, pulverized leaves and roots were subjected to phytochemical analysis to screen for the presence of secondary metabolites such as Alkaloids, Tannins, Saponin, Resins, Flavonoids, Glycosides, 
Steroids, Phenols, Terpenoid, Cardiac glycosides and Triterpenoids. The phytochemical screening was carried out using standard procedure (Sofowora, 1993 and Trease and Evans, 2002).

\subsubsection{Quantitative screening}

\subsubsection{Alkaloid determination}

$2.5 \mathrm{~g}$ of the powder was extracted using 100 $\mathrm{ml}$ of $20 \%$ acetic acid in ethanol. The solution was covered for almost 4 hours. Filtrate was concentrated to $25 \mathrm{ml}$. Concentrated ammonium hydroxide was added stepwise to attain precipitation. The whole solution was kept as such so that precipitate will settle. Collected precipitate was washed with dilute ammonium hydroxide and finally filtered. Filtrate was discarded and pellet obtained was dried and weighed (Edeoga et al., 2005 and Okwu and Josiah, 2006).

\subsubsection{Saponin determination}

$10 \mathrm{~g}$ of sample was mixed with $100 \mathrm{ml}$ of $20 \%$ aqueous ethanol. The mixture was kept for 4 hours on water bath shaker at $55^{\circ} \mathrm{C}$. Filtrate was again extracted in same manner. The combined extract was concentrated to $40 \mathrm{ml}$ over water bath at $90^{\circ} \mathrm{C}$. Concentrate obtained was transferred into a separating funnel and $10 \mathrm{ml}$ of diethyl ether was added to it. After shaking vigorously aqueous layer was recovered and ether layer was discarded. The process was repeated. To the aqueous layer nbutanol was added. The whole mixture was washed in separating funnel twice with $10 \mathrm{ml} 5 \%$ of aqueous $\mathrm{NaCl}$. Upper part was retained and heated in water bath until evaporation. Latter it was dried in oven to a constant weight (Obadoni and Ochuko, 2001; Edeoga et al., 2005).

\subsubsection{Tannins determination}

$2 \mathrm{~g}$ of plant powder was extracted thrice in $70 \%$ acetone. After centrifuging the sample supernatant was removed. Different aliquots were taken and final volume to $3 \mathrm{ml}$ was adjusted by distilled water. The solution after vortexing were mixed with $1 \mathrm{ml}$ of $0.016 \mathrm{M} \mathrm{K} 3 \mathrm{Fe}(\mathrm{CN})_{6}$, followed by 1 $\mathrm{ml}$ of $0.02 \mathrm{M} \mathrm{FeCl}_{3}$ in $0.10 \mathrm{M} \mathrm{HCl}$. Vortexing was repeated and the tubes were kept as such for $15 \mathrm{~min}$. $5 \mathrm{ml}$ of stabilizer (3:1:1 ratio of water, $\mathrm{H}_{3} \mathrm{PO}_{4}$ and $1 \%$ gum arabic) was added followed by revortexing. Absorbance was measured at $700 \mathrm{~nm}$ against blank. Standard curve was plotted using various concentrations of $0.001 \mathrm{M}$ gallic acid (Graham, 1992).

\subsubsection{Carbohydrate determination}

$0.5 \mathrm{~g}$ of plant material was extracted with $80 \%$ ethanol. Extract was dissolved in $10 \mathrm{ml}$ water.
Different aliquots were prepared and final volume was made to $1 \mathrm{ml}$ by water. $5 \mathrm{ml}$ of $96 \%$ of concentrated $\mathrm{H}_{2} \mathrm{SO}_{4}$ was added followed by shaking and incubation for $40 \mathrm{~min}$ at room temperature. $1 \mathrm{ml}$ of $5 \%$ phenol was added to each tube and absorbance was taken at $490 \mathrm{~nm}$. Standard curve using different concentrations of $25 \mathrm{mg} \%$ glucose (Krishnaveni et al., 1984).

\subsubsection{Proteins determination}

$1 \mathrm{~g}$ plant material was extracted using $10 \mathrm{ml}$ water added with few drops of triton X- 100. Supernatant was extracted in acetone and the pellet obtained was dissolved in $0.1 \mathrm{M} \mathrm{NaOH}$. Aliquots were prepared and final volume was made to $1 \mathrm{ml}$ by distilled water. $5 \mathrm{ml}$ of copper reagent was added to tubes, mixed well and incubated for 10 minutes. $1 \mathrm{ml}$ of folin's reagent was mixed. Tubes were incubated for $30 \mathrm{~min}$ at room temperature and absorbance was taken at $700 \mathrm{~nm}$. Standard curve was prepared using $50 \mathrm{mg} \%$ BSA (Lowry et al., 1951).

\subsubsection{Lipids determination}

$1 \mathrm{~g}$ plant sample was dissolved in ether and stirred for a hour. Mixture was centrifuged, supernatant dried and dissolved in ethanol. $0.1 \mathrm{ml}$ of alcohol was taken as blank, olive oil as standard and test sample as unknown respectively. $2 \mathrm{ml}$ of concentrated $\mathrm{H}_{2} \mathrm{SO}_{4}$ and $5 \mathrm{ml}$ of phosphovanillin reagent was added and mixed well, incubated for 30 min. Absorbance was read at 540nm (Ganai et al., 2005).

\section{RESULTS AND DISCUSSION}

The results of preliminary phytochemical study were tabulated in Table- 1 . The phytochemical study revealed the presence of steroids, flavonoids, alkaloids, coumarins, triterpenoids, tannins and carbohydrate. The table-2 shows the Quntitative Phytochemical Screening which is measured in $\mathrm{g} \%$. The Physicochemical Analysis is described with physical nature, extractive value and ash value in table-3.

Alkaloids which are one of the largest groups of phytochemicals in plants have amazing effects on humans and this has led to the development of powerful pain killer medications (Kam and Liew, 2002). Just et al. (1998) revealed the inhibitory effect of saponins on inflamed cells. Saponin was found to be present in C.maxicana extracts and has supported the usefulness of this plant in managing inflammation. Flavonoids, another constituent of C.maxicana leaves, stem and rhizome extracts exhibited a wide range of biological activities like antimicrobial, anti-inflammatory, anti- 
angionic, analgesic, anti-allergic, cytostatic and antioxidant properties .The result justifies the use of these plants in traditional medicine for the treatment of various kinds of diseases including infectious disease (Idu et al., 2006).

\section{CONCLUSION}

This study has shown the scientific basis for some of the therapeutic uses of C.maxicana plant in traditional medicine. The preliminary phytochemical tests are helpful in finding chemical constituents in the plant material that may lead to their quantitative estimation and also in locating the source of pharmacologically active chemical compound.

\section{REFERENCES}

Argueta V.A., A.L.M. Cano and M.E. Rodarte. (1994). Atlas De Las De La Medicina Tradicional Mexicana I. Institute Nacional Indigenista, Mexico.

Caceres A., L.M. Grion and A.M. Martinez. (1987). Diuretic activity of plants used for the treatment of urinary ailments in Guatemala. $J$ Ethnopharmacol, 19, 233-245.

Comargo M.E.M., C.R. Najera, R.S. Torres, M.E.C. Alderate. (2006). Evaluation of the Diuretic Effect of the Aqueous Extract of Costus pictus D. Don in Rat. Poc West Pharmacol Soc, 49, 72-74.

Edeoga H.O., D.E.Okwu and B.O. Mbaebie. (2005). Phytochemical constituents of some Nigerian medicinal Plant. African J. Biotechnology, 4(7): 685- 688.

Farnsworth N.R. (1966). Biological and phytochemical screening of plants. J. Pharm. Sci. 55: 225-276

Ganai B.A., A. Masood and M.A. Zargar. (2005). Experimental Biochemistry, 1st ed., Valley Publications, J\&K, pp.148-149.

Graham H.D. (1992). Prussian Blue Assay. J. Agric Food Chem., 40: 801-805.

Idu M., B.C. Ndukwu. (2006). Studies of plants used in ethnomedicine in Ethiope council Area of Delta state, Nigeria. Research Journal of botany.1(1):30-43.

Just M.J., M.C. Recio, R.M. Giner, M.J. Cueller, S. Manez, A.R. Bilia and J.L. Rios. (1998). Antiinflammatory activity of unusual lupine saponins from Bupleurum fruticescens. Planta Medica. 64: 404-407.

Kam P.C.A., Liew (2002). Traditional Chinese herbal medicine and anaesthesia. Anaesthesia 57(11): 1083-1089.
Krishnaveni S., B. Theymoli and S. Sadasivam. (1984). Phenol Sulpuric acid method. Food Chem., 15: 229.

Lowry O.H., N.J. Rose brough, A.L. Farr and R.L. Randall. (1951). Protein measurements with the Folin-Phenol reagent. J. Biol. Chem., 193: 265-275.

Martinez M. (1996). Las Plantas Medicinales De Mexico, Andres Botas, 6th Edn, Mexico.

Merina B. (2004). Natural Product Radiance, 3: 349350.

Merina B.( 2005). Toxicity studies of the herb Costus pictus D. Don. Pharmainfo. net. http://www.pharmainfo.net/ review/toxicitystudies-herb-costus-pictus-d-don,.

Nandhakumar Jothivel, Sethumathi Pudupalayam Ponnusamy, Malini Appachi, Sengottuvelu Singaravel, Duraisamy Rasilingam, Karthikeyan Deivasigamani and Sivakumar Thangavel. (2007). Antidiabetic activity of methanol extract of Costus pictusD. Don. in Alloxan induced Diabetic rats. J. Health Sci. 53(6): 655663.

Obdoni B.O. and P.O. Ochuko. (2001). Phytochemical studies and comparative efficacy of the crude extracts of some Homostatic plants in Edo and Delta States of Nigeria. Global J. Pure Appl. Sci., 8: 203-208.

Okwu D.E. and C. Josiah. (2006). Evaluation of the chemical composition of two Nigerian Medicinal plants. African J. Biotechnology., 5(4): 357-361.

Rzedowski J. and G.Rzedowski. (1979). Flora Fanerogamica del valle de Mexico. 3rd Edn. Continental. Mexico.

Shubha and Anusuya D.(2010) Antioxidant and nutrient content of micropropagated costus pictus inoculated with beneficial soil microorganisms. Adv. Plant Sciences,. (In press to be published in 2010)

Sofowora A. ( 1993) Screening plants for Bioactive Agents. In: Medicinal plants and Tradditonal Medicine in Africa. (2nd Edn.), Spectrum Books Ltd, Sonshine House, Ibadan, Nigeria, PP: 134156.

Trease G.E. and W.C. Evans. (2002). Pharmacognosy. (15th Edn.), Sawnders Publishers, London,, PP: 42:44. 
Table 1: Qulalitative Phytochemical Screening of Costus Maxicana

\begin{tabular}{|c|c|c|c|c|c|c|c|c|c|}
\hline \multirow{2}{*}{ Bioactive Agents } & \multicolumn{3}{|c|}{ Petroleum ether } & \multicolumn{3}{|c|}{ Acetone } & \multicolumn{3}{|c|}{ Ethanol } \\
\hline & $\mathrm{L}$ & $\mathrm{S}$ & $\mathrm{R}$ & $\mathrm{L}$ & $\mathrm{S}$ & $\mathrm{R}$ & $\mathrm{L}$ & $\mathrm{S}$ & $\mathrm{R}$ \\
\hline Alkaloid & + & + & + & + & + & + & + & + & + \\
\hline Flavanoid & + & + & + & + & + & + & + & + & + \\
\hline Saponin & - & - & + & - & - & - & - & - & + \\
\hline Glycoside & + & + & - & + & + & - & + & - & - \\
\hline Tanin & - & - & + & - & - & + & - & - & - \\
\hline Terpenoid & + & + & + & + & + & + & + & + & + \\
\hline Resin & + & + & + & + & + & - & - & & - \\
\hline Steroid & + & - & + & + & + & + & + & + & + \\
\hline Phenol & + & + & - & - & + & - & - & + & - \\
\hline Cardiac glycoside & + & + & + & - & + & + & - & + & + \\
\hline Tri-terpenoids & + & - & - & - & - & - & + & - & + \\
\hline
\end{tabular}

Table 2: Quntitative Phytochemical Screening of Costus Maxicana

\begin{tabular}{cccc}
\hline Bioactive & \multicolumn{3}{c}{$\begin{array}{c}\text { Quantity/100g of plant } \\
\text { material* (i.e. g \%) }\end{array}$} \\
Agents & $\mathrm{L}$ & $\mathrm{S}$ & $\mathrm{R}$ \\
Alkaloid & $1.53 \pm 0.02$ & $1.18 \pm 0.05$ & $1.73 \pm 0.01$ \\
Tannins & $0.05 \pm 0.001$ & $0.03 \pm 0.03$ & $0.06 \pm 0.003$ \\
Saponins & $0.35 \pm 0.0025$ & $0.47 \pm 0.04$ & $0.21 \pm 0.03$ \\
Flavonoids & $1.73 \pm 0.036$ & $1.33 \pm 0.064$ & $1.47 \pm 0.043$ \\
Cardiac Glycosides & $0.056 \pm 0.005$ & $0.067 \pm 0.007$ & $0.032 \pm 0.003$ \\
Carbohydrates & $0.375 \pm 0.0012$ & $0.474 \pm 0.006$ & $0.659 \pm 0.004$ \\
Lipids & $2.44 \pm 0.002$ & $2.96 \pm 0.003$ & $4.69 \pm 0.006$ \\
Proteins &
\end{tabular}

*Results are mean \pm SD of triplicate determination on the basis of dry weight.

Table 3: Physicochemical Analysis of Costus Maxicana

\begin{tabular}{|c|c|c|c|c|}
\hline \multirow[t]{2}{*}{ S.No. } & \multirow[t]{2}{*}{ Parameters } & \multicolumn{3}{|c|}{ Observation } \\
\hline & & Leaves & Stem & Rhizome \\
\hline \multirow[t]{4}{*}{ I } & Physical test & & & \\
\hline & Nature & Smooth & Scaly & Scaborous \\
\hline & Colour & Dark green & Greenish yellow & Brown \\
\hline & Odour & Odourless & Pungent smell & Pungent smell \\
\hline \multirow[t]{4}{*}{ II } & Extractive value & & & \\
\hline & Petroleum ether & 8.45 & 6.82 & 7.5 \\
\hline & Acetone & 9.29 & 7.34 & 9.26 \\
\hline & Ethanol & 11.86 & 10.62 & 9.36 \\
\hline III & Loss of Drying & $9.53 \%$ & & \\
\hline \multirow{4}{*}{ IV } & Ash Value & & & \\
\hline & Total ash & 9.2 & 7.8 & 8.8 \\
\hline & Acid insoluble ash & 2.7 & 3.9 & 2.3 \\
\hline & Water soluble ash & 3.1 & 3.6 & 2.4 \\
\hline
\end{tabular}

